\title{
9. CALCAREOUS NANNOFOSSILS FROM THE NANKAI TROUGH AND JAPAN TRENCH, DEEP SEA DRILLING PROJECT LEG 871
}

\author{
Thomas H. Lang, Department of Geology, Florida State University, Tallahassee
}

\begin{abstract}
Drilling at three DSDP drill sites on the western margin of the Pacific Ocean off the coast of Japan yielded thick sequences of hemipelagic muds and clays generally depleted of calcareous nannofossils. Operations at Sites 582 and 583 recovered dominantly Quaternary sediments. The Pliocene/Pleistocene boundary was reached near the bottom of Hole 582B. At both sites, preserved coccolith populations contained generally few to common nannoliths. The effects of reworking were evident throughout most sections at these two sites. Drilling at Site 584 in the Japan Trench recovered Holocene to Miocene sediments. Populations of nannofossils from this site were generally more depleted than those from the two Nankai Trough sites. Reworking within these sections appears to be much less severe than in samples from the more southern sites.
\end{abstract}

\section{INTRODUCTION}

During Leg 87 of the Deep Sea Drilling Project, 14 holes were drilled at three sites on the western margin of the Pacific Ocean off the coast of Japan. The principal objectives of this leg were to study the changes in the physical and mechanical properties of sediments brought on by subduction within an active convergent margin system. The cruise was divided into two parts; the first of these, Leg 87A, included drilling at Sites 582 and 583 in the Nankai Trough off the southern island of Shikoku (Fig. 1). During the second part, Leg 87B, drilling that had been interrupted by mechanical problems at Site 583 was completed, and a third site, Site 584 , was drilled farther north off the northern end of Honshu.

The purpose of this report is to provide an initial summary of the calcareous nannofossil biostratigraphy of the sediments recovered from these three Leg 87 sites. This summary includes analyses of the abundance, diversity, and preservation of nannofossil assemblages, as observed with both the light microscope and the scanning electron microscope.

\section{METHODS AND PROCEDURES}

Leg 87 recovered cores from the western margin of the Pacific Ocean at water depths ranging from 4086 to, $4879 \mathrm{~m}$. Light microscopic techniques, primarily, were used in the examination of 501 samples. Smear slides were prepared directly from raw sediment in order to examine the true abundance of coccoliths and other nannoliths. Nannofossils in some samples were concentrated using a settling technique, a particularly useful process for samples suspected of containing the tiny upper Pleistocene marker species, Emiliania huxleyi. These concentrated samples were examined with a Cambridge IV Stereoscan scanning electron microscope to determine the presence or absence of E. huxleyi.

The species abundances are described using a format similar to that outlined by Hay (1970). Hay's format, in part, is as follows:

$\mathrm{R}=$ rare; 1 specimen in 101-1000 fields of view at $1000 \times$

$F=$ few; 1 specimen in $11-100$ fields of view at $1000 \times$

\footnotetext{
${ }^{1}$ Kagami, H., Karig, D. E., Coulbourn, W. T., et al., Init. Repts. DSDP, 87: Washington (U.S. Govt. Printing Office)

2 Address: Department of Geology, Florida State University, Tallahassee, FL 32306.
}

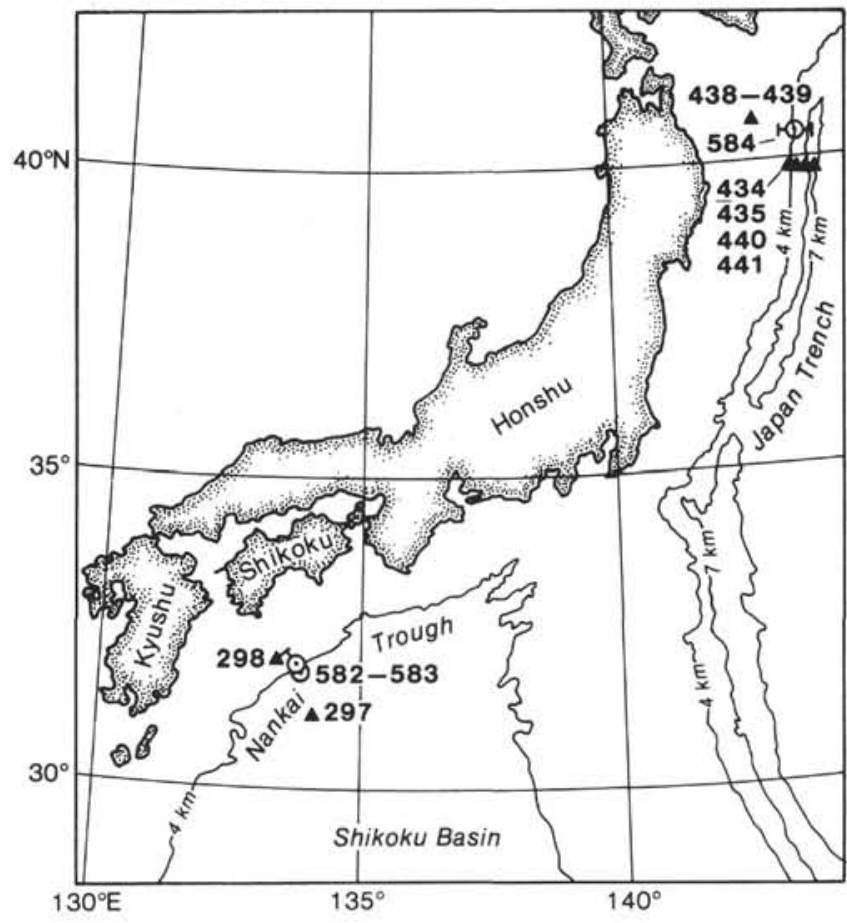

Figure 1. Locations of DSDP Leg 87 drill sites.

$\mathrm{C}=$ common; 1 specimen in $2-10$ fields of view at $1000 \times$

$\mathrm{A}=$ abundant; $1-10$ specimens per field of view at $1000 \times$.

No nannofossil species is present in Leg 87 samples in numbers greater than can be accurately described using this part of Hay's format. The single difference between the scheme used in this study and that of Hay is in the use, here, or a magnification of $1560 \times$ instead of the $1000 \times$ used by Hay. The higher magnification used here was beneficial in the identification of minute Pleistocene species that were the dominant forms encountered in Leg 87 sediments.

The nomenclature used in Hay's original method of estimating abundances is somewhat misleading when used to describe sediments with generally depleted nannofloral populations. In the case of coccoliths from the Nankai Trough and Japan Trench, Gephyrocapsa oceanica is clearly the most dominant form present. In a few samples, this species is the only form observed. In these samples, the species abundance of $G$. oceanica by itself is sometimes high enough to be called 


\section{T. H. LANG}

"common," following the Hay scheme. The word "common" in these cases seems to give an erroneous impression regarding the overall abundance of total nannofossils in the sample. For that reason, an additional outline, one that can qualitatively describe the abundance of all the nannofossils in a given assemblage, the population abundance, has been drawn up. The outline is as follows:

b = barren; no nannofossils present

$\mathrm{r}=$ rare; 1 nannofossil in 2-10 fields of view at $1560 \times$

$\mathrm{f}=\mathrm{few} ; 1-10$ nannofossils per field of view at $1560 \times$

$c=$ common; $10-100$ nannofossils per field of view at $1560 \times$.

Letters on the range charts corresponding to the population abundance are shown as lower case. Those denoting species abundances are shown as upper case.

A qualitative description of the preservation of nannofossils is provided, using the outline described by Lang and Watkins (1984). The outline is as follows:

$\mathrm{VG}=$ very good; no evidence of secondary alteration via etching and/or overgrowth

$\mathrm{G}$ = good; little evidence of secondary alteration via etching and/ or overgrowth, identification of species not impaired
M = moderate; significant evidence of secondary alteration via etching and/or overgrowth, identification of species not impaired

$\mathrm{P}$ = poor; specimens typically heavily overgrown or severely etched, identification of some species significantly impaired.

The initial shipboard analysis employed zonation schemes modeled after those by Martini (1970) and Gartner (1977). Both schemes make use of the prominent extinction datum of Pseudoemiliania lacunosa. Gartner's (1977) scheme also makes use of the extinctions of Helicosphaera sellii and Calcidiscus macintyrei. More intensive examinations during the shore-based follow-up study revealed a higher degree of reworking than was initially observed. For that reason, the zonation scheme used for this study is that of Bukry $(1973,1975)$ with the supplemental modifications of Okada and Bukry (1980). The use of evolutionary first occurrences of marker species in this zonation makes it more suitable to the reworked sediments recovered on Leg 87 (Figs. 2 and 3).

Citations for the nannofossil species listed in the Appendix are taken from Loeblich and Tappan, 1966; 1968; 1969; 1970a, b; 1971; 1973, and from van Heck, 1979a, b; 1980a, b; 1981a, b; 1982a, b; 1983.

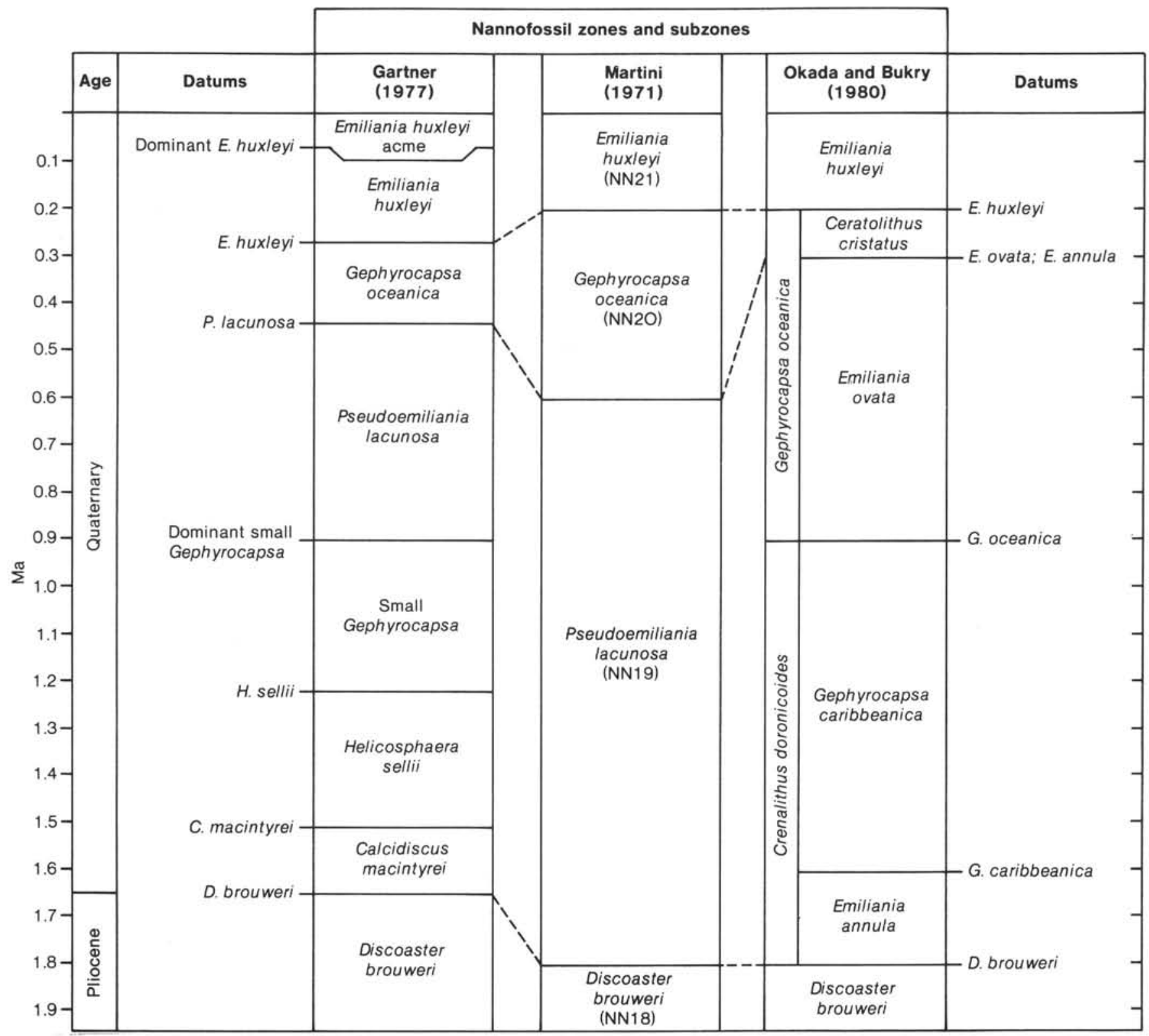

Figure 2. Quaternary zonation schemes employed for this study. 


\begin{tabular}{|c|c|c|c|c|c|c|c|}
\hline Age & & Zone & & Subzone & $\begin{array}{c}\text { Martini } \\
\text { (1971) } \\
\text { zone }\end{array}$ & $\begin{array}{l}\text { Dura- } \\
\text { tion } \\
\text { (Ma) }\end{array}$ & $\begin{array}{l}\text { Bound- } \\
\text { ary } \\
\text { (Ma) }\end{array}$ \\
\hline \multirow{4}{*}{ Quat. } & CN15 & Emiliania huxleyi & & & $\mathrm{NN} 21$ & 0.2 & 0.2 \\
\hline & $\mathrm{CN} 14$ & Gephyrocapsa & $\mathrm{CN} 14 \mathrm{~b}$ & Ceratolithus cristatus & $\mathrm{NN} 20$ & 0.1 & 0.3 \\
\hline & & oceanica & & Emiliania ovata & & & 0.9 \\
\hline & \multirow[t]{3}{*}{$\mathrm{CN} 13$} & \multirow[t]{3}{*}{$\begin{array}{l}\text { Crenalithus } \\
\text { doronicoides }\end{array}$} & $\begin{array}{l}\mathrm{CN} 13 \mathrm{~b} \\
\mathrm{CN} 13 \mathrm{a}\end{array}$ & $\begin{array}{l}\text { Gephyrocapsa caribbeanica } \\
\text { Emiliania annula }\end{array}$ & NN19 & $\begin{array}{l}0.7 \\
0.2\end{array}$ & $\begin{array}{l}1.6 \\
1.8\end{array}$ \\
\hline \multirow{7}{*}{ Plio. } & & & CNI2d & Calcidiscus macintyrei & NN18 & 0.2 & 2.0 \\
\hline & & & $\mathrm{CN} 12 \mathrm{c}$ & Discoaster pentaradiatus & NN17 & 0.1 & 2.1 \\
\hline & $\mathrm{CN} 12$ & Discoaster brouweri & $\begin{array}{l}\text { CN12b } \\
\text { CN12a }\end{array}$ & $\begin{array}{l}\text { D. surculus } \\
\text { D. tamalis }\end{array}$ & NN16 & $\begin{array}{l}0.4 \\
0.5\end{array}$ & 2.5 \\
\hline & $C \mathrm{NH}$ & Reticulofenestra & CNIIb & D. asymmetricus & NNU5 & 0.5 & 35 \\
\hline & CNII & pseudoumbilica & $\mathrm{CNI} 1 \mathrm{a}$ & Sphenolithus neoabies & NINIS & 0.5 & 4.0 \\
\hline & \multirow{2}{*}{ CN10 } & \multirow{2}{*}{$\begin{array}{l}\text { Amaurolithus } \\
\text { tricorniculatus }\end{array}$} & CNIOc & \multirow{2}{*}{$\begin{array}{l}\text { Ceratolithus rugosus } \\
\text { Ceratolithus acutus } \\
\text { Triquetrorhabdulus rugosus }\end{array}$} & $13 / 14$ & 0.4 & 4.4 \\
\hline & & & CN10a & & $\mathrm{NN} 12$ & 0.6 & $\begin{array}{l}5.0 \\
5.6\end{array}$ \\
\hline \multirow{11}{*}{ Mio. } & CN9 & Discoaster & $\mathrm{CN} 9 \mathrm{~b}$ & Amaurolithus primus & NN川 & 1.0 & \\
\hline & CNA & quinqueramus & $\mathrm{CN} 9 \mathrm{a}$ & D. berggrenii & NNII & 0.4 & 7.0 \\
\hline & CN8 & Discoaster & $\mathrm{CN} 8 \mathrm{~b}$ & D. neorectus & NN10 & 0.5 & 7.5 \\
\hline & & $\begin{array}{l}\text { neohamatus } \\
\text { Discoaster }\end{array}$ & $\begin{array}{l}\text { CN8a } \\
\text { CN7b }\end{array}$ & $\begin{array}{l}\text { D. bellus } \\
\text { Catinaster calyculus }\end{array}$ & & $\begin{array}{l}3.5 \\
1.0\end{array}$ & 11.0 \\
\hline & $\mathrm{CN} 7$ & hamatus & $\mathrm{CN} 7 \mathrm{a}$ & Helicosphaera carteri & NN9 & 1.0 & $\begin{array}{l}12.0 \\
13.0\end{array}$ \\
\hline & CN6 & Catinaster coalitus & & & NN8 & 0.2 & 132 \\
\hline & CN5 & Discoaster & CN5b & D. kugleri & NN7 & 0.2 & \\
\hline & & exilis & CN5a & Coccolithus miopelagicus & NN6 & 0.6 & 14.0 \\
\hline & $\mathrm{CN} 4$ & \multirow{3}{*}{\multicolumn{2}{|c|}{$\begin{array}{l}\text { Sphenolithus hetermorphus } \\
\text { Helicosphaera ampliaperta } \\
\text { S. belemnos }\end{array}$}} & & NN5 & 1.0 & 15.0 \\
\hline & $\mathrm{CN}^{2}$ & & & & - & 2.0 & 17.0 \\
\hline & CN2 & & & & NN2 & & 18.0 \\
\hline \multirow{8}{*}{ Oligo. } & $\mathrm{CN} 1$ & Triquetrorhabdulus & CNlc & D. druggii & & $\begin{array}{l}3.0 \\
2.0\end{array}$ & 21.0 \\
\hline & & carinatus & $\mathrm{CNla}$ & Cyclicargolithus abisectus & NNI & 1.0 & $\begin{array}{l}23.0 \\
24.0\end{array}$ \\
\hline & CP19 & Sphenolithus & $\mathrm{CP} 19 \mathrm{~b}$ & Dictyococcites bisectus & NP25 & 1.0 & 25.0 \\
\hline & & ciperoensis & CP19a & Cyclicargolithus floridanus & NP24 & 1.5 & 26.5 \\
\hline & $\begin{array}{l}\text { CP18 } \\
\text { CP17 }\end{array}$ & $\begin{array}{l}\text { S. distentus } \\
\text { S. predistentus }\end{array}$ & & & NP23 & $\begin{array}{l}3.5 \\
4.0\end{array}$ & 30.0 \\
\hline & & & CP16c & Reticulofenestra hillae & NP22 & 0.5 & \\
\hline & CP16 & Helicosphaera & $\mathrm{CP} 16 \mathrm{~b}$ & Coccolithus formosus & 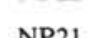 & 2.5 & 34.5 \\
\hline & & & CP16a & Coccolithus subdistichus & NP21 & 1.0 & $\begin{array}{l}37.0 \\
38.0\end{array}$ \\
\hline \multirow{12}{*}{ Eoc. } & CP15 & D. barbadiensis & $\mathrm{CP} 15 \mathrm{~b}$ & Isthmolithus recurvus & $19 / 20$ & 3.0 & 41.0 \\
\hline & & & CP15a & Chiasmolithus oamc & NP18 & 1.0 & 42.0 \\
\hline & $\mathrm{CP} 14$ & Reticulofenestra & CP14b & D. saipanensis & NP17 & 2.0 & 44.0 \\
\hline & & & & & NP16 & & 45.0 \\
\hline & $\mathrm{CP} 13$ & Nannotetrina & CP13c & Coccolithus staurion & & 1.5 & 46.5 \\
\hline & - 10 & auadrata & CP13a & D. strictus & NP15 & $\begin{array}{l}0.3 \\
1.0\end{array}$ & 47.0 \\
\hline & CP12 & $D$ sublodoensis & $\mathrm{CP} 12 \mathrm{~b}$ & Rhabdosphaera inflata & NDIA & 1.0 & 48.0 \\
\hline & Chis & D. sublodoenisis & CP12a & Discoasteroides kuepperi & NP14 & 0.5 & $\begin{array}{l}490 \\
49.5\end{array}$ \\
\hline & CP11 & \multirow{2}{*}{\multicolumn{2}{|c|}{$\begin{array}{l}\text { D. Iodoensis } \\
\text { Tribrachiatus orthostylus }\end{array}$}} & & $12 / 13$ & 0.5 & \\
\hline & CP10 & & & & 12713 & 2.0 & 52.0 \\
\hline & CP9 & $D$ diastynus & СР9b & Discoaster binodosus & NP1I & 0.8 & \\
\hline & $C>$ & D. anastypus & CP9a & Tribrachiatus contortus & NP10 & 0.7 & $\begin{array}{l}52.8 \\
53.5\end{array}$ \\
\hline \multirow{9}{*}{ Paleoc. } & CP8 & D. multiradiatus & CP8b & Campylosphaera eodela & NP9 & 0.5 & 54.0 \\
\hline & & \multicolumn{2}{|l|}{ D. nobilis } & Chiasmoliths & & & 55.0 \\
\hline & CP6 & \multirow{2}{*}{\multicolumn{2}{|c|}{$\begin{array}{l}\text { D. mohleri } \\
\text { Heliolithus kleinpellii }\end{array}$}} & & $7 / 8$ & 0.5 & 55.5 \\
\hline & CP5 & & & & NP6 & 1.0 & 57.0 \\
\hline & $\mathrm{CP} 4$ & \multicolumn{2}{|c|}{ Fasciculithus tympaniformis } & & NP5 & 20 & 58.0 \\
\hline & CP3 & \multicolumn{2}{|l|}{ Ellipsolithus macellus } & & NP4 & & 60.0 \\
\hline & $\mathrm{CP} 2$ & \multicolumn{2}{|l|}{ Chiasmolithus danicus } & & NP3 & & \\
\hline & CP1 & Zygodiscus & CPIb & Cruciplacolithus tenuis & NP2 & & \\
\hline & $\mathrm{Cr}_{1}$ & sigmoides & CP1a & Cruciplacolithus orimus & NP1 & & 65.0 \\
\hline
\end{tabular}

Figure 3. Cenozoic coccolith zones and subzones and corresponding code numbers, from Okada and Bukry, 1980. 


\section{SUMMARY OF NANNOFOSSIL BIOSTRATIGRAPHY}

Site $582\left(31^{\circ} 46.5^{\prime} \mathrm{N}, \mathbf{1 3 3}^{\circ} 54.8^{\prime} \mathrm{E}\right.$; water depth $\left.4879 \mathrm{~m}\right)$

Sites 582 and 583, in the Nankai Trough, were intended to complement each other. Site 582, in the undeformed sediments accumulating in the Trough axis, was drilled to recover a reference section for physical properties, structure, and stratigraphy (see site chapter, Site 582 , this volume). Drilling in three holes at this site penetrated $807 \mathrm{~m}$ of sediment, $749 \mathrm{~m}$ of which was drilled in Hole 582B. The dominantly hemipelagic muds in this hole range from Holocene to upper Pliocene.

Drilling in Holes 582 and 582A recovered a total of only five cores. All the samples examined from these five cores contain nannofossil assemblages of the Emiliania huxleyi Zone. Assemblages from both of these holes were dominated in every case by Gephyrocapsa oceani$c a$. Other forms present in varying abundances include E. huxleyi, G. caribbeanica, Calcidiscus leptoporus, Coccolithus pelagicus, and Umbilicosphaera mirabilis.

The first five cores from Hole 582B, down to Sample 582B-5-2, 44-45 cm, contain the uppermost Quaternary marker species, E. huxleyi (Table 1). Other forms present include G. oceanica, C. leptoporus, Helicosphaera carteri, U. mirabilis, and Syracosphaera pulchra. Reworking of sediments in this hole is illustrated by the presence of such forms as Reticulofenestra pseudoumbilica and a few persistent discoaster species typical of older sediments. The interval from $582 \mathrm{~B}-7-1,85-86 \mathrm{~cm}$ to $582 \mathrm{~B}-59-1,85-86 \mathrm{~cm}$ is assigned to the $G$. oceanica Zone. Generally, samples from this interval lack $E$. huxleyi and contain few to abundant $G$. oceanica and few to common $G$. caribbeanica. The underlying $G$. caribbeanica Zone spans a much shorter interval, from 582B-59-3, $72-73 \mathrm{~cm}$ to $582 \mathrm{~B}-68, \mathrm{CC}$. The first rare though consistent discoaster debris occurs near the bottom of this interval, an indication of the Pliocene/Pleistocene boundary. Below a barren interval from 582B-69, CC to 582B$70-2,24-26 \mathrm{~cm}$, the first consistent occurrences of both discoaster debris and whole specimens of Discoaster brouweri are in Sample 582B-70-2, 67-68 cm. The Pliocene/Pleistocene boundary was placed above this sample but below the interval containing only rare discoaster debris. Drilling at Site 582 was terminated upon reaching Pliocene sediments, and the Glomar Challenger moved to Site 583 .

\section{Site $583\left(31^{\circ} 50.0^{\prime} \mathrm{N}, \mathbf{1 3 3}^{\circ} 51.4^{\prime} \mathrm{E}\right.$; water depth $\left.4634 \mathrm{~m}\right)$}

Site 583 was drilled in the Nankai Trough on the deepest structural terrace landward of the Trench axis (see site chapter, Site 583, this volume). In this area, highresolution seismic profiles show a well-developed thrust fault. The primary objectives here were to study subduction and accretion processes. A series of mechanical problems brought the number of holes drilled at this site to eight. A total of $1700 \mathrm{~m}$ of Holocene to Pleistocene hemipelagic muds with interspersed silty and sandy in- tervals was penetrated before the approach of Typhoon Bess forced abandonment of the site.

$$
\text { Holes 583, 583A, 583B, 583C }
$$

Holes 583, 583A, 583B, and 583C were hydraulic-piston cored. Samples from these four holes contain Quaternary nannofossils in various states of preservation and abundance. In Hole 583, the uppermost Quaternary marker species, Emiliania huxleyi, occurs in samples down to $583-5-3,64-65 \mathrm{~cm}$ (Table 2). This interval is assigned to the E. huxleyi Zone, and all the sediments below this interval are assigned to the Gephyrocapsa oceanica Zone. Nannofossil forms most commonly found in this interval include $G$. oceanica, G. caribbeanica, Helicosphaera carteri, Coccolithus pelagicus, Syracosphaera pulchra, Umbilicosphaera mirabilis, Calcidiscus leptoporus, and Crenalithus doronicoides.

Barren samples in the uppermost cores from Holes $583 \mathrm{~A}$ and 583B prevent exact delineation of the boundary between the E. huxleyi and $G$. oceanica zones in these holes. The first section of Core 3 from both holes (583A-3-1, 44-45 cm and 583B-3-1, 19-20 cm) contains $E$. huxleyi, and the intervals above these samples are assigned to the E. huxleyi Zone. This interval is followed, in both holes, by barren intervals below which no $E$. huxleyi was observed. In Hole 583A, sediments below $583 \mathrm{~A}-6-1,10-11 \mathrm{~cm}$ are assigned to the $G$. oceanica Zone (Table 3). In Hole 583B, sediments below 583B-4-3, 43$44 \mathrm{~cm}$, to the end of coring, are also assigned to the $G$. oceanica Zone.

Hole $583 \mathrm{C}$ was washed to a sub-bottom depth of $25 \mathrm{~m}$, where Core $583 \mathrm{C}-1$ was retrieved. All samples examined from this hole, with one exception, are barren of nannofossils or contain depleted, poorly preserved populations that are not age-diagnostic. Sample 583C-3-3, 39$40 \mathrm{~cm}$ contains nannoliths of the $G$. oceanica Zone.

\section{Holes 583D, 583E, 583F, 583G}

Rotary coring at Site 583 was undertaken in Holes $583 \mathrm{D}, 583 \mathrm{E}, 583 \mathrm{~F}$, and $583 \mathrm{G}$. Because all four holes were washed to some sub-bottom depth before the start of rotary drilling, the uppermost sediments were not recovered (see site chapter, Site 583, this volume). Consequently, the youngest sediments recovered are assigned to the Gephyrocapsa oceanica Zone (Tables 4-6). The most commonly encountered forms present in samples from these holes are G. oceanica, G. caribbeanica, and Crenalithus doronicoides; $G$. oceanica is by far the most dominant species. Other forms commonly observed include Helicosphaera carteri, Coccolithus pelagicus, Syracosphaera pulchra, Umbilicosphaera mirabilis, Calcidiscus leptoporus, and Pseudoemiliania lacunosa. The sporadic occurrence of reworked forms such as Reticulofenestra pseudoumbilica and various discoaster species required strict adherence to the Bukry $(1973,1975)$ zonation scheme, which utilizes evolutionary first occurrences as zonal markers. A prominent seismic reflector, interpreted as a thrust fault, was not recognized by any reversal in the age of nannofossil assemblages from 
Hole 583D. Samples in the vicinity of this structural horizon are all assigned to the $G$. oceanica Zone.

\section{Site $584\left(40^{\circ} 28.0^{\prime} \mathrm{N}, \mathbf{1 4 3}^{\circ} 57.6^{\prime} \mathrm{E}\right.$; water depth $\left.4086 \mathrm{~m}\right)$}

Site 584 was drilled in the Japan Trench off northern Honshu (Fig. 1). In addition to the general cruise objectives mentioned earlier, one objective of drilling at this site was to investigate the history of vertical motion of part of the continental margin adjacent to the Trench itself. The investigation of this continental block, the Oyashio landmass, was to be achieved by drilling through a pervasive unconformity below the overlying cover of slope sediments. The site was drilled landward of the Trench axis on a deep-sea terrace. A total of $981 \mathrm{~m}$ of sediment was cored in three holes at this site; of this total, $954 \mathrm{~m}$ were cored in Hole 584. Sediments from this site range from Quaternary to middle Miocene.

Nannofossils at Site 584 are markedly rarer and more poorly preserved than those observed in samples from the more southern sites. Of the 192 samples examined, $78 \%$ are barren of nannofossils, severely limiting the coherence of the nannofossil stratigraphy at this site.

Samples 584-1-1, 54-56 cm through 584-1-1, 54-56 cm are barren of nannofossils. Pliocene species of the Discoaster tamalis Subzone were encountered in Sample $584-1-5,54-56 \mathrm{~cm}$. The most common forms observed in this assemblage are Calcidiscus leptoporus, C. macintyrei, Coccolithus pelagicus, Discoaster brouweri, D. pentaradiatus, $D$. surculus, and $D$. tamalis. This assemblage persists through Sample 584-12-1, 30-31 cm. A barren interval from $584-12-3,30-31 \mathrm{~cm}$ to $584-13-1$, $25-26 \mathrm{~cm}$ is followed by the appearance of an assemblage that includes Reticulofenestra pseudoumbilica and Sphenolithus abies in Sample 584-13-2, 16-17 cm. The last-occurrence datums of these forms delineate the upper boundary of the $R$. pseudoumbilica Zone. The occurrence of $D$. asymmetricus is inconsistent in samples assigned to the $R$. pseudoumbilica Zone. Therefore, the subdivision of this interval (from 584-13-2, 16-17 cm to 584-23-1, 68-79 cm) into subzones, following Bukry's scheme, is impractical. Samples from the interval between 584-23-3, 55-57 $\mathrm{cm}$ and 584-27-2, 83-84 cm are barren of nannofossils. Below these samples, Samples 584-27-5, 83-84 cm through 584-29-2, 7-8 cm also contain nannofossils of the $R$. pseudoumbilica Zone.

Another sequence of barren samples (from 584-30-1, $59-60 \mathrm{~cm}$ to $584-37-6,78-79 \mathrm{~cm}$ ) is followed, in Sample 584-37, CC, by the highest stratigraphic occurrence of Amaurolithus primus. Samples from this level down to 584-38-4, 12-13 cm are thus assigned to the Amaurolithus tricorniculatus Zone, which spans the Pliocene/Miocene boundary. Again, the scarcity of nannofossils and the resultant irregular occurrences of marker species prevent subdivision of this important interval into subzones. Additional samples obtained to help further delineate this boundary were barren of nannofossils. The most often encountered species in samples assigned to this zone include Calcidiscus leptoporus, C. macintyrei, Coccolithus pelagicus, $D$. brouweri, $D$. pentaradiatus, $D$. sur- culus, Helicosphaera carteri, R. pseudoumbilica, and $S$. abies. A. primus is consistently rare in these samples.

The highest occurrence of Discoaster quinqueramus was noted in Sample 584-47-1, 20-21 cm. Sediments from this level down to $584-56-1,99-100 \mathrm{~cm}$ are assigned to the upper Miocene D. quinqueramus Zone. The assemblage from this interval is similar to that in the overlying A. tricorniculatus Zone, with the addition of $D$. quinqueramus. Samples below this section are barren of nannofossils or contain rare, poorly preserved assemblages that are not age-diagnostic. Poorly preserved specimens of Cyclicargolithus floridanus occur in 584-93-1, 81-82 $\mathrm{cm}$, which could indicate an age as young as middle Miocene (Bukry, 1973; 1975). However, age-diagnostic forms of similar age, such as D. kugleri and Catinaster coalitus, were not observed.

Spot cores and wash cores from Holes 584A and 584B were examined for nannofossils. Samples from these holes are barren or contain rare, undiagnostic forms.

\section{CONCLUSIONS AND SUMMARY OF OBSERVATIONS}

The most significant feature of the Leg 87 samples is the general paucity of nannofossils as a whole. Owing to the corrosiveness of waters at depth in both the Nankai Trough and the Japan Trench, nannofossil diversity is extremely low and preservation is typically poor. These facts, coupled with the high number of barren samples, act as severe restrictions to the coherence of the coccolith stratigraphy of Leg 87 sites.

In spite of the low diversity and poor preservation of Leg 87 coccolith assemblages, a few comparisons with earlier DSDP studies in the area are still possible. Leg 31 drilled at several sites in the Phillipine Sea (Karig, Ingle, et al., 1975). One site from that leg was drilled in the Nankai Trough southwest of Site 582 (Fig. 1). Additionally, during Legs 56 and 57, a transect across the Japan Trench was drilled in the vicinity of Site 584 (Scientific Party, 1980).

The diversity of nannofossils from Site 298 (Ellis, 1975 ) is as low as the diversity observed in samples from Site 582. At both sites, discoasters are reworked in the sections containing dominantly Quaternary forms. The sporadic occurrence of the ubiquitous species Coccolithus pelagicus is also noted at both of these Nankai Trough sites.

The nannofossils recovered during Leg 56 are described by Haq and Goreau (1980). Those recovered during Leg 57 are discussed by Schaffer (1980). Both of these initial studies report assemblages similar to those observed in samples from Site 584. The number of barren samples, however, is much greater at Site 584. In all three cases, Quaternary assemblages seem to lack the persistent reworked discoaster component seen in samples from the Nankai Trough. In addition, the distinctive, cosmopolitan species Coccolithus pelagicus is a consistent member of the populations. Its presence contrasts sharply with the sporadic occurrences of this form in samples from the Nankai Trough. 


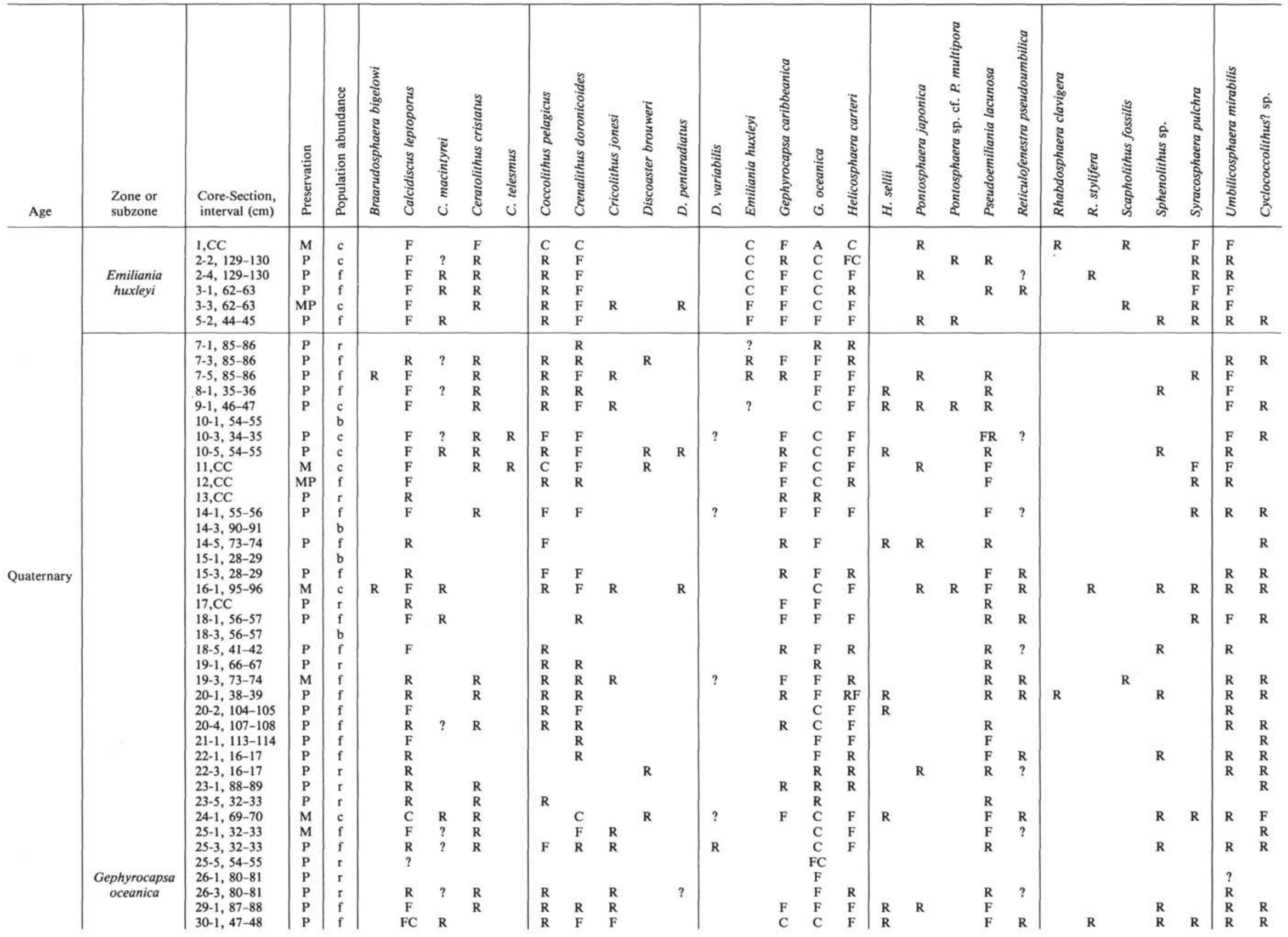




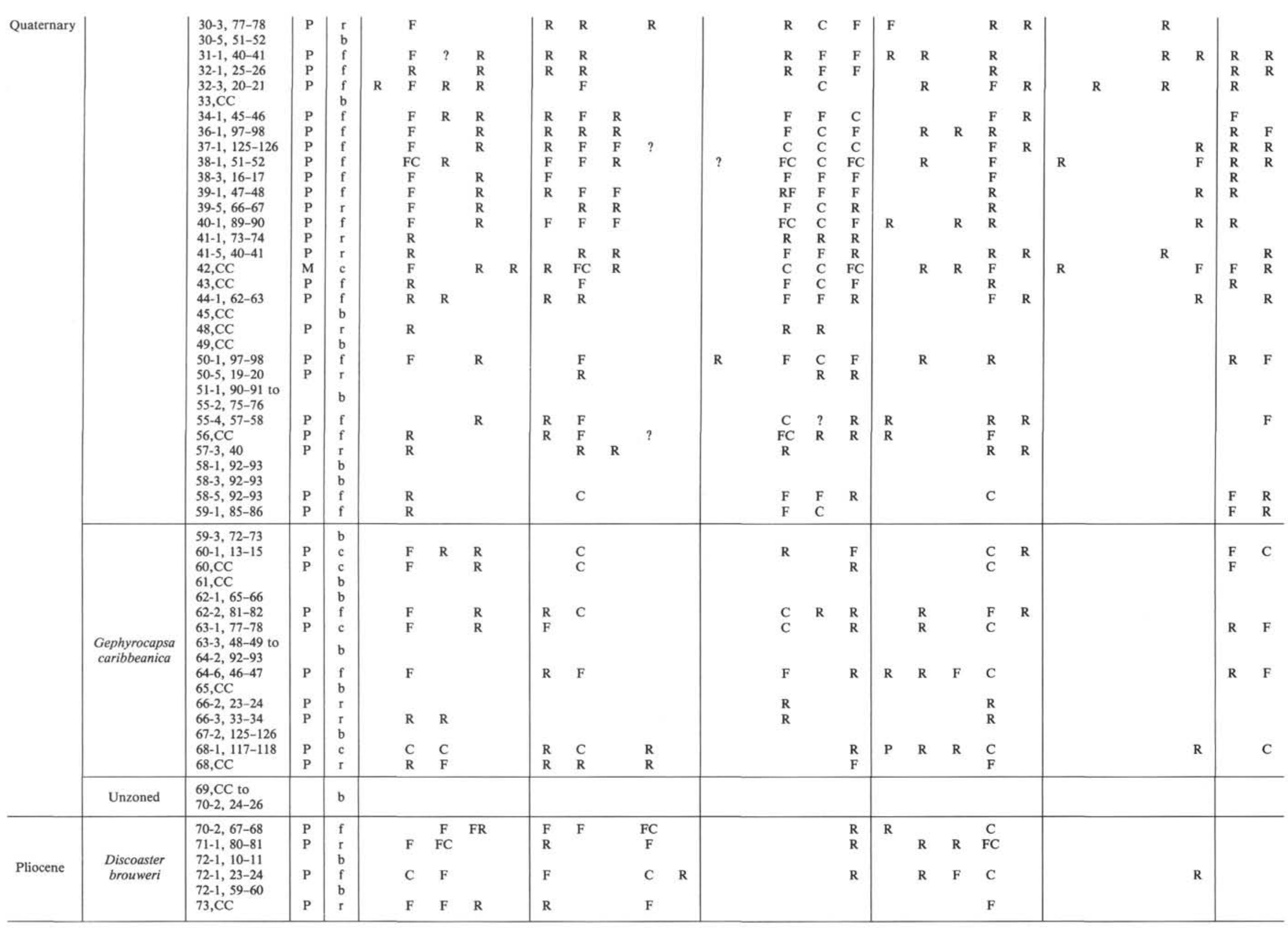


Table 2. Distribution of nannofossils in Hole 583.

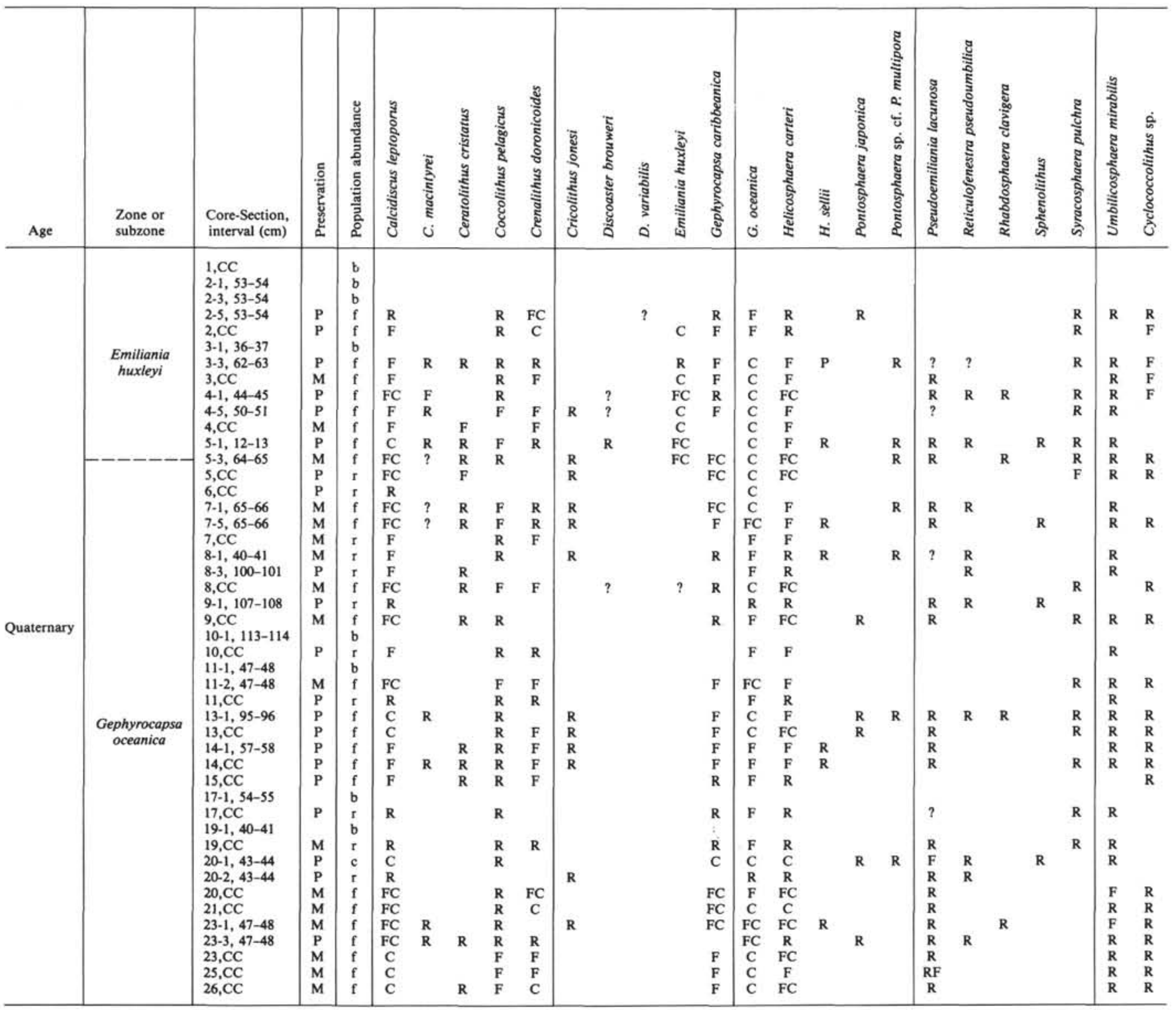

Note: See text for key to abbreviations.

The problems posed by reworking and poor preservation at great depths in both the Nankai Trough and the Japan Trench demand a certain amount of caution in dealing with calcareous nannofossils from these areas. Although rapid sedimentation and pronounced turbidity current activity in the Nankai Trough undoubtedly had an effect on the reworking of older fossils there, a more guarded approach should be taken to simple explanations for nannofossil occurrences in the Japan Trench. Lack of preservation is detrimental to the biostratigraphy of sediments at these trench depths. Its probable effects upon the first- and last-appearance datums of calcareous nannofossils significantly reduces the biostratigraphic resolution achievable in these sediments. Without concentration techniques or some other method of enhancing the abundance of coccoliths in each sample, the feasibility of incorporating sediments from these depths into paleoceanographic or paleobiogeographic studies based on calcareous nannofossils is limited.

\section{REFERENCES}

Bukry, D., 1973. Low latitude coccolith biostratigraphic zonation. In Edgar, N. T., Saunders, J. B., et al., Init. Repts. DSDP, 15: Washington (U.S. Govt. Printing Office), 685-703.

1975. Coccolith and silicoflagellate stratigraphy, northwestern Pacific Ocean, Deep Sea Drilling Project Leg 32. In Larson, R. L., Moberly, R., et al., Init. Repts. DSDP, 32: Washington (U.S. Govt. Printing Office), 677-701.

Ellis, C. H., 1975. Calcareous nannofossil biostratigraphy, Leg 31, Deep Sea Drilling Project. In Karig, D. E., Ingle, J. C., Jr., et al., Init. Repts. DSDP, 31: Washington (U.S. Govt. Printing Office), 655-676.

Gartner, S., 1977. Calcareous nannofossil biostratigraphy and revised zonation of the Pleistocene. Mar. Micropaleontol., 2:1-25.

Haq, B. U., and Goreau, M., 1980. Calcareous nannofossils from the Japan Trench upper slope, Leg 56, Deep Sea Drilling Project. In 
Scientific Party, Init. Repts. DSDP, 56, 57, Pt. 2: Washington (U.S. Govt. Printing Office), 867-873.

Hay, W. W., 1970. Calcareous nannofossils from cores recovered on Leg 4. In Bader, R. G., Gerard, R. D., et al., Init. Repts. DSDP, 4: Washington (U.S. Govt. Printing Office), 455-501.

Karig, D. E., Ingle, J. C., Jr., et al., 1975. Init. Repts. DSDP, 31: Washington (U.S. Govt. Printing Office).

Lang, T. H., and Watkins, D. K., 1984. Cenozoic calcareous nannofossils from Deep Sea Drilling Project Leg 77. In Buffler, R. T., Schlager, W., et al., Init. Repts. DSDP, 77: Washington (U.S. Govt. Printing Office), 629-648.

Loeblich, A. R., Jr., and Tappan, H., 1966. Annotated index and bibliography of the calcareous nannoplankton, I. Phycologia, 5:81216.

1968. Annotated index and bibliography of the calcareous nannoplankton, II. J. Paleontol., 42:584-598.

1969. Annotated index and bibliography of the calcareous nannoplankton, III. J. Paleontol., 43:568-588.

1970a. Annotated index and bibliography of the calcareous nannoplankton, IV. J. Paleontol., 44:558-574.

1970b. Annotated index and bibliography of the calcareous nannoplankton, V. Phycologia, 9:157-174.

, 1971. Annotated index and bibliography of the calcareous nannoplankton, VI. Phycologia, 10:315-339.

, 1973. Annotated index and bibliography of the calcareous nannoplankton, VII. J. Paleontol., 47:715-759.

Martini, E., 1970. Standard Tertiary and Quaternary calcareous nannoplankton zonation. Proc. Second Conf. Planktonic Microfossils (Vol. 2), 739-786.

Okada, H., and Bukry, D., 1980. Supplementary modification and introduction of code numbers to the low-latitude coccolith biostratigraphic zonation (Bukry, 1973; 1975). Mar. Micropaleontol., 5:321325.

Schaffer, B. L., 1980. Calcareous nannofossil biostratigraphy of Japan Trench transect, Deep Sea Drilling Project Leg 57. In Scientific Party, Init. Repts. DSDP, 56, 57, Pt. 1: Washington (U.S. Govt. Printing Office), 875-886.

Scientific Party, 1980. Init. Repts. DSDP, 56, 57: Washington (U.S. Govt. Printing Office).

van Heck, S. E., 1979a. Bibliography and taxa of calcareous nannoplankton. Int. Nannoplankton Assoc. Newsl., 1:AB1-5, A1-12, B127.

1979b. Bibliography and taxa of calcareous nannoplankton. Int. Nannoplankton Assoc. Newsl., 1:AB VI, A13-28, B28-42. ,1980a. Bibliography and taxa of calcareous nannoplankton. Int. Nannoplankton Newsl., 2:5-34.

, 1980b. Bibliography and taxa of calcareous nannoplankton. Int. Nannoplankton Newsl., 2:43-81.

, 1981a. Bibliography and taxa of calcareous nannoplankton. Int. Nannoplankton Newsl., 3:4-41.

1981b. Bibliography and taxa of calcareous nannoplankton. Int. Nannoplankton Newsl., 3:51-86.

1982a. Bibliography and taxa of calcareous nannoplankton. Int. Nannoplankton Newsl., 4:7-50. 1982b. Bibliography and taxa of calcareous nannoplankton. Int. Nannoplankton Newsl., 4:65-96. 1983. Bibliography and taxa of calcareous nannoplankton.

Int. Nannoplankton Newsl., 5:4-13.

Date of Initial Receipt: 26 April 1984

Date of Acceptance: 5 March 1985

\section{APPENDIX}

\section{Nannofossil Species Considered in This Report}

Sphenolithus abies Deflandre, 1953

Ceratolithus acutus (Bukry) Gartner and Bukry, 1974

Pontosphaera anisotrema (Kamptner) Backman, 1980

Discoaster asymmetricus Gartner, 1969

Discoaster berggrenii Bukry, 1971

Braarudosphaera bigelowii (Gran and Braarud) Deflandre, 1947

Discoaster brouweri Tan, 1927

Gephyrocapsa caribbeanica Boudreaux and Hay, 1967

Helicosphaera carteri (Wallich) Kamptner, 1954

Rhabdosphaera clavigera Murray and Blackman, 1898

Cyclococcolithus cricotus Gartner, 1967

Ceratolithus cristatus Kamptner, 1950

Crenalithus doronicoides (Black and Barnes) Roth, 1973

Helicosphaera euphratis Haq, 1966

Scapholithus fossilis Deflandre, 1954

Emiliania huxleyi (Lohmann) Hay and Mohler, in Hay, Mohler, Roth, and Boudreaux, 1967

Discoaster intercalaris Bukry, 1971

Pontosphaera japonica (Takayama) Romein, 1979

Cricolithus jonesi Cohen, 1965

Pseudoemiliania lacunosa (Kamptner) Gartner, 1969

Calcidiscus leptoporus (Murray and Blackman) Loeblich and Tappan, 1978

Calcidiscus macintyrei (Bukry and Bramlette) Loeblich and Tappan, 1978

Coccolithus minutus (Kamptner) Loeblich and Tappan, 1978

Umbilicosphaera mirabilis Lohmann, 1902

Pontosphaera multipora (Bramlette and Sullivan) Romein, 1979

Sphenolithus neoabies Bukry and Bramlette, 1969

Gephyrocapsa oceanica Kamptner, 1943

Coccolithus pelagicus (Wallich) Schiller, 1930

Discoaster pentaradiatus Tan, 1927

Reticulofenestra pseudoumbilica (Gartner) Gartner, 1969

Amaurolithus primus (Bukry and Percival) Gartner and Bukry, 1975

Syracosphaera pulchra Lohmann, 1902

Discoaster quinqueramus Gartner, 1969

Helicosphaera sellii (Bukry and Bramlette) Jafar and Martini, 1975

Rhabdosphaera stylifera Lohmann, 1902

Discoaster surculus Bramlette and Martini, 1963

Discoaster tamalis Kamptner, 1967

Ceratolithus telesmus Norris, 1965

Discoaster variabilis Bramlette and Martini, 1963 
Table 3. Distribution of nannofossils in Hole 583A.

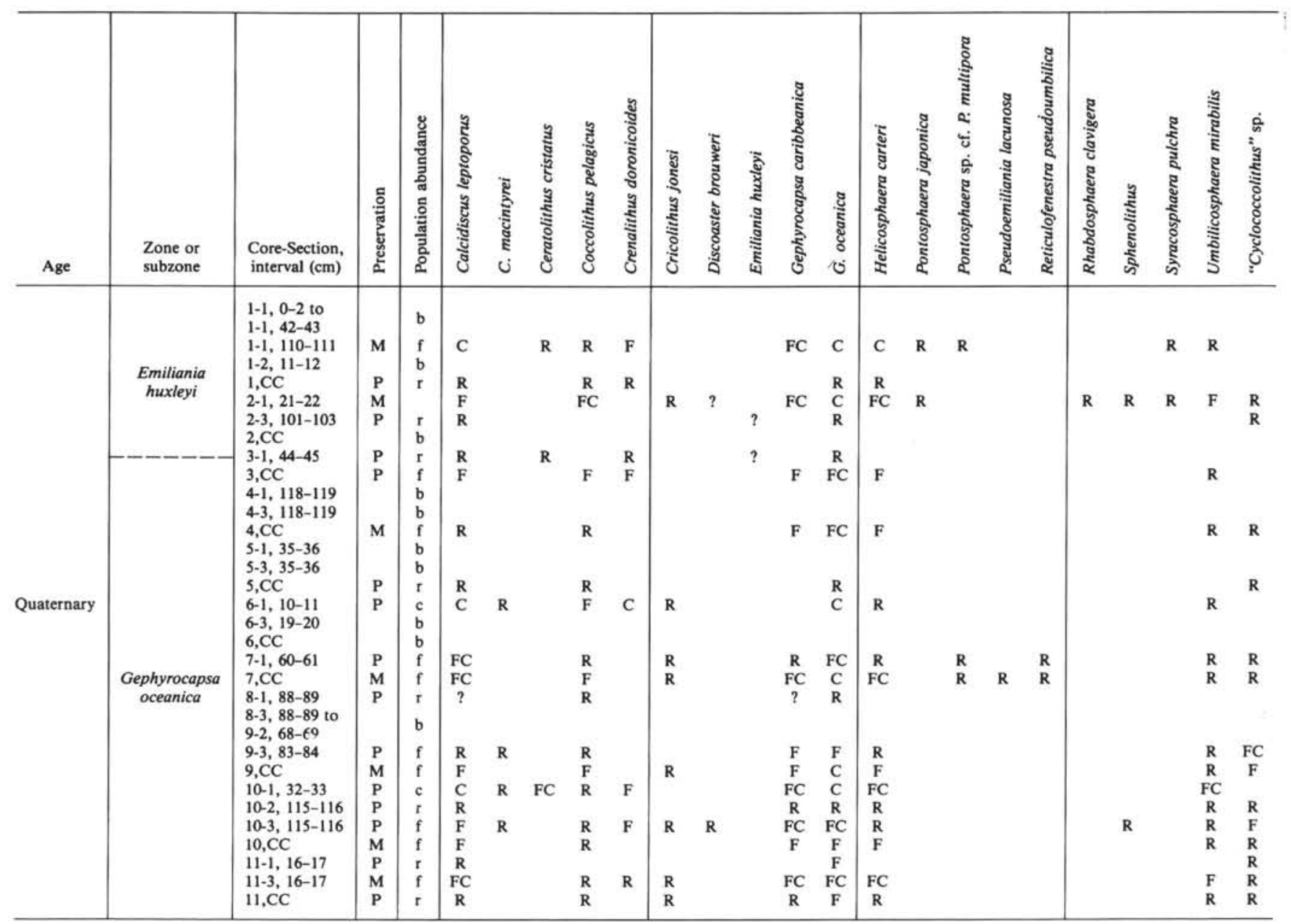

Note: See text for key to abbreviations. 
Table 4. Distribution of nannofossils in Hole 583D.

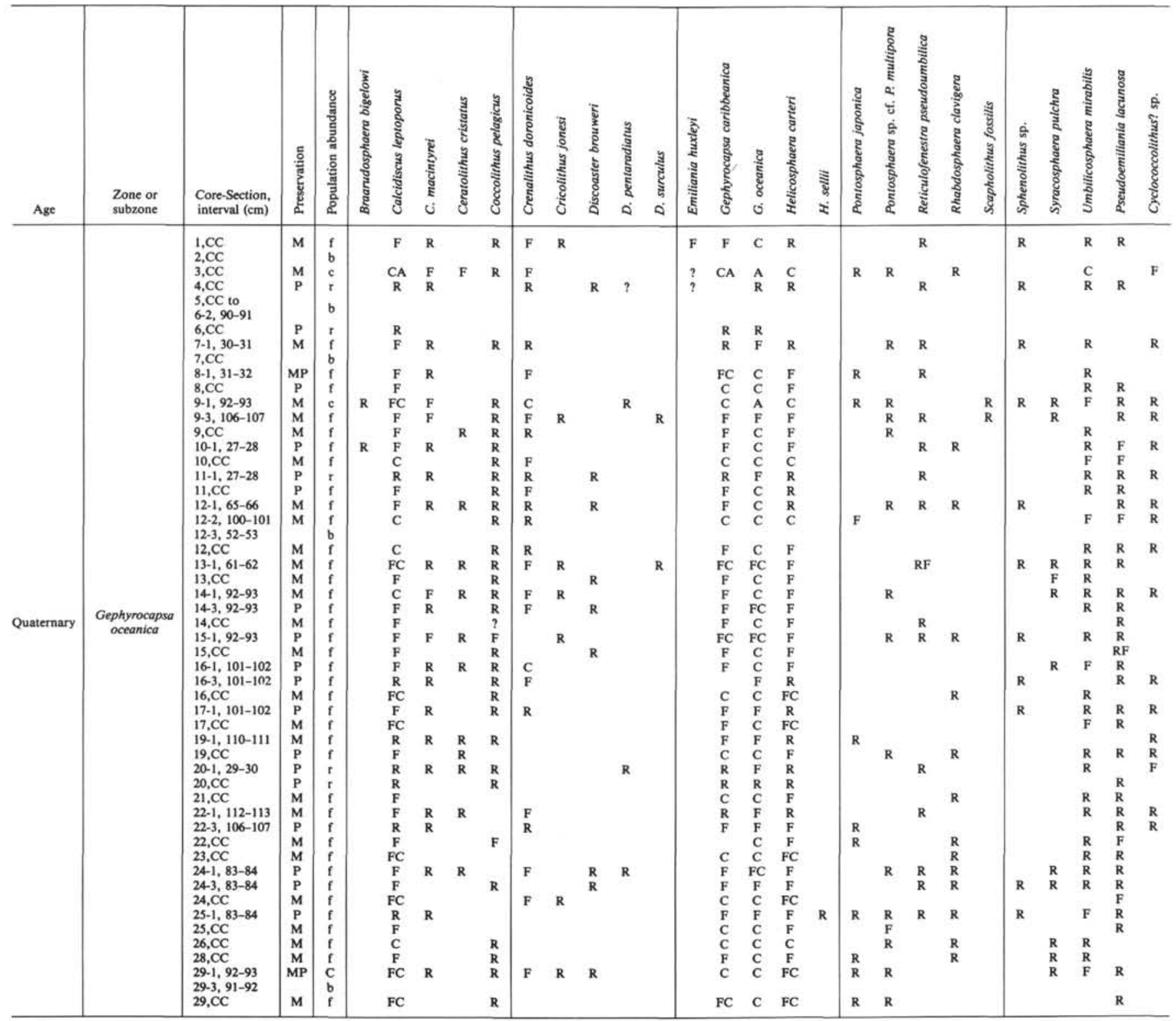

Note: See text for key to abbreviations. 
Table 5. Distribution of nannofossils in Hole 583F.

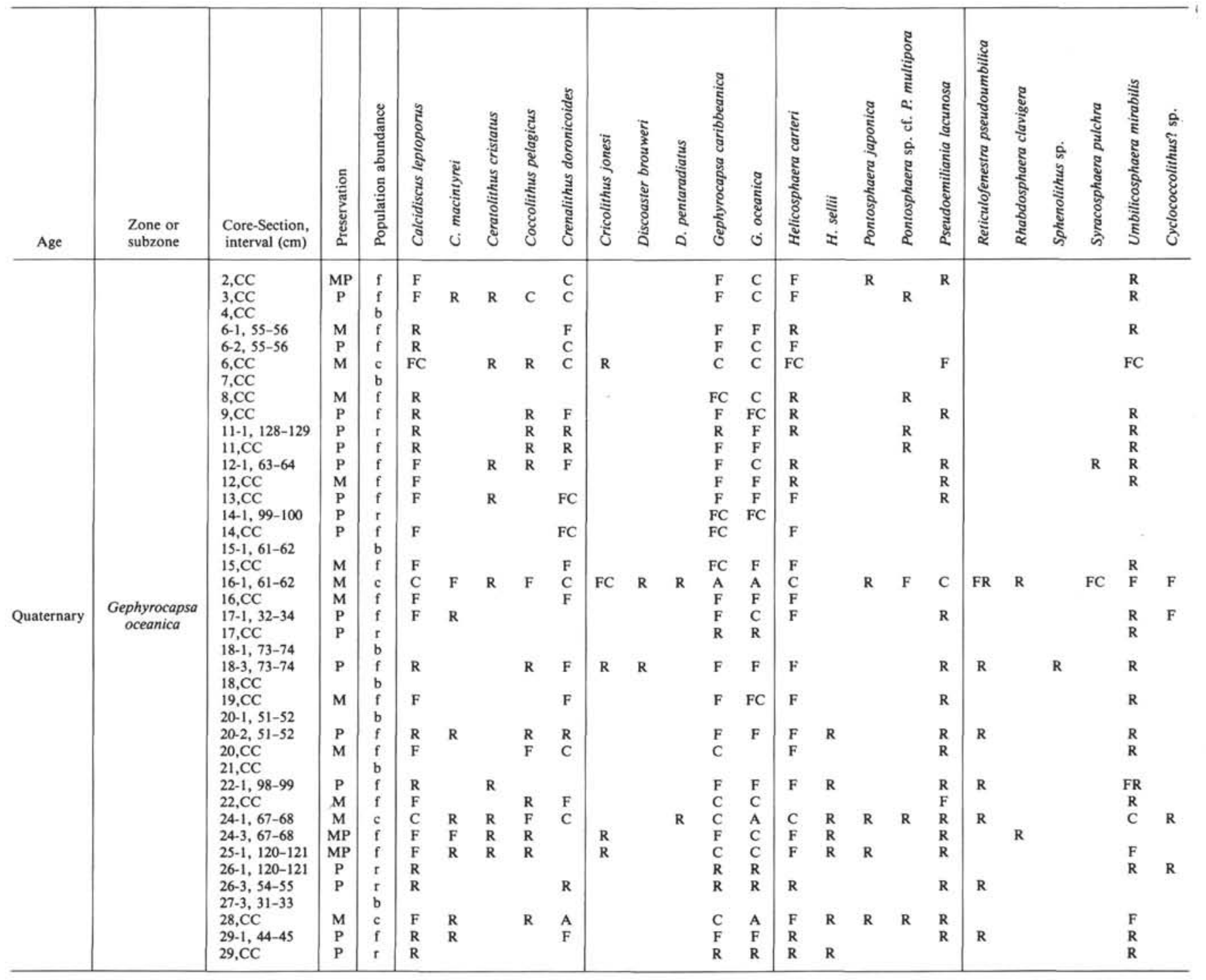

Note: See text for key to abbreviations. 
Table 6. Distribution of nannofossils in Hole 583G.

\begin{tabular}{|c|c|c|c|c|c|c|c|c|c|c|c|c|c|c|c|c|c|c|c|c|c|c|}
\hline Age & $\begin{array}{l}\text { Zone or } \\
\text { subzone }\end{array}$ & $\begin{array}{l}\text { Core-Section, } \\
\text { interval }(\mathrm{cm})\end{array}$ & 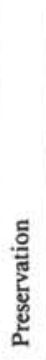 & 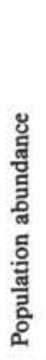 & 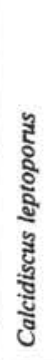 & 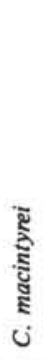 & 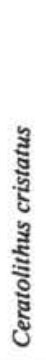 & 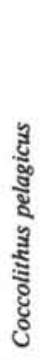 & 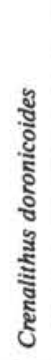 & 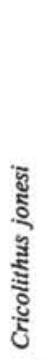 & 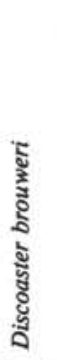 & 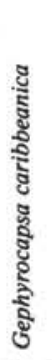 & 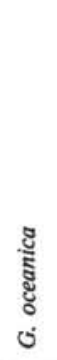 & 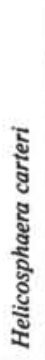 & 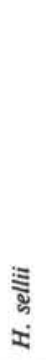 & 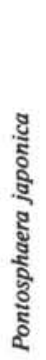 & 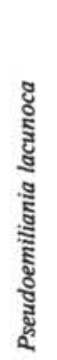 & 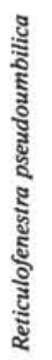 & 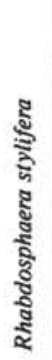 & 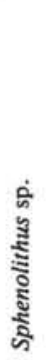 & 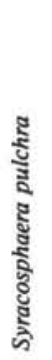 & 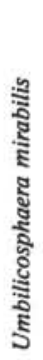 \\
\hline Quaternary & $\begin{array}{c}\text { Gephyrocapsa } \\
\text { oceanica }\end{array}$ & $\begin{array}{l}1-1,94-95 \\
1-3,54-55 \\
2-1,70-71 \\
2-3,70-71 \\
3-2,46-47 \\
3-3,123-124 \\
4-1,64-65 \\
4-3,64-65 \\
5-1,61-62 \\
5-2,61-62 \\
6-2,47-48 \\
6-3,47-48 \\
7-1,49-50 \\
7-3,54-55 \\
8-2,10-11 \\
8-3,10-11 \\
10-2,31-32 \\
10-5,26-27 \\
11-2,50-51 \\
12, C C \\
13, C C \\
14, C C \\
15-1,128-129 \\
15, C C\end{array}$ & $\begin{array}{l}\mathrm{P} \\
\mathrm{P} \\
\mathrm{P} \\
\mathrm{M} \\
\mathrm{M} \\
\\
\mathrm{P} \\
\mathrm{P} \\
\mathrm{M} \\
\mathrm{M} \\
\\
\mathrm{P} \\
\mathrm{P} \\
\mathrm{M} \\
\mathrm{M} \\
\mathrm{M} \\
\mathrm{M} \\
\mathrm{P} \\
\mathrm{M} \\
\mathrm{P} \\
\mathrm{P} \\
\mathrm{P}\end{array}$ & $\begin{array}{l}\text { b } \\
b \\
\text { f } \\
\text { r } \\
\text { f } \\
\text { f } \\
\text { f } \\
\mathrm{b} \\
\mathrm{f} \\
\mathrm{f} \\
\mathrm{c} \\
\mathrm{c} \\
\mathrm{b} \\
\mathrm{r} \\
\mathrm{r} \\
\mathrm{f} \\
\mathrm{f} \\
\mathrm{f} \\
\mathrm{f} \\
\mathrm{f} \\
\mathrm{c} \\
\mathrm{f} \\
\mathrm{f} \\
\mathrm{r}\end{array}$ & $\begin{array}{c}\mathrm{R} \\
\mathrm{F} \\
\mathrm{R} \\
\mathrm{F} \\
\mathrm{F} \\
\mathrm{F} \\
\mathrm{F} \\
\mathrm{C} \\
\mathrm{C} \\
\\
\mathrm{R} \\
\mathrm{R} \\
\mathrm{F} \\
\mathrm{F} \\
\mathrm{F} \\
\mathrm{FC} \\
\mathrm{R} \\
\mathrm{F} \\
\mathrm{F} \\
\mathrm{R} \\
\mathrm{R}\end{array}$ & $\begin{array}{l}\mathrm{R} \\
\mathrm{R} \\
\mathrm{R}\end{array}$ & $\begin{array}{l}\mathrm{R} \\
\mathrm{R} \\
\mathrm{R}\end{array}$ & $\begin{array}{l}\mathbf{R} \\
\mathbf{R} \\
\mathrm{R} \\
\mathrm{R}\end{array}$ & $\begin{array}{c}\mathrm{F} \\
\mathrm{F} \\
\mathrm{F} \\
\mathrm{R} \\
\mathrm{F} \\
\mathrm{CF} \\
\mathrm{FC} \\
\mathrm{C} \\
\mathrm{C} \\
\mathrm{R} \\
\mathrm{R} \\
\mathrm{F} \\
\mathrm{F} \\
\mathrm{F} \\
\mathrm{FC} \\
\mathrm{R} \\
\mathrm{R} \\
\mathrm{F}\end{array}$ & $\begin{array}{l}\mathrm{R} \\
\mathrm{R} \\
\mathrm{R} \\
\mathrm{R} \\
\mathrm{R} \\
\mathrm{F}\end{array}$ & $\mathbf{R}$ & $\begin{array}{c}\text { C } \\
\text { F } \\
\text { F } \\
\text { CF } \\
\text { C } \\
\text { C } \\
\\
\text { F } \\
\text { R } \\
\text { F } \\
\text { FC } \\
\text { F } \\
\text { FC } \\
\text { F } \\
\text { A } \\
\text { F } \\
\text { R } \\
\text { R }\end{array}$ & $\begin{array}{c}\mathrm{F} \\
\mathrm{C} \\
\mathrm{FC} \\
\mathrm{F} \\
\mathrm{C} \\
\mathrm{C} \\
\mathrm{C} \\
\mathrm{A} \\
\mathrm{A} \\
\\
\mathrm{F} \\
\mathrm{F} \\
\mathrm{F} \\
\mathrm{C} \\
\mathrm{C} \\
\mathrm{C} \\
\mathrm{F} \\
\mathrm{A} \\
\mathrm{F} \\
\mathrm{FC} \\
\mathrm{R}\end{array}$ & $\begin{array}{l}\mathbf{R} \\
\mathbf{F} \\
\mathbf{R} \\
\mathrm{R} \\
\mathrm{F} \\
\mathrm{F} \\
\mathrm{R} \\
\mathrm{C} \\
\mathrm{C} \\
\mathrm{R} \\
\\
\mathrm{F} \\
\mathrm{R} \\
\mathrm{R} \\
\mathrm{F} \\
\mathrm{R} \\
\mathrm{C} \\
\mathbf{R} \\
\mathrm{F} \\
\mathrm{R}\end{array}$ & $\begin{array}{l}\mathbf{R} \\
\mathbf{R}\end{array}$ & $\begin{array}{l}\mathbf{R} \\
\mathbf{R} \\
\mathbf{R} \\
\mathbf{R}\end{array}$ & $\begin{array}{c}\mathrm{R} \\
\mathrm{F} \\
\mathrm{R} \\
\mathrm{R} \\
\mathrm{R} \\
\mathrm{R} \\
\mathrm{F} \\
\mathrm{F}\end{array}$ & $\begin{array}{l}\mathrm{R} \\
\mathrm{R}\end{array}$ & $\begin{array}{l}\mathrm{R} \\
\mathrm{R}\end{array}$ & $\begin{array}{l}\mathbf{R} \\
\mathrm{R} \\
\mathrm{R}\end{array}$ & $\begin{array}{l}\mathbf{R} \\
\mathrm{F}\end{array}$ & $\begin{array}{l}\mathbf{R} \\
\mathbf{F} \\
\mathbf{F} \\
\mathbf{F} \\
\mathbf{R} \\
\mathbf{F} \\
\mathbf{R} \\
\mathrm{R}\end{array}$ \\
\hline
\end{tabular}

Note: See text for key to abbreviations. 